\title{
Strategi Mempertahankan Brand Knowledge Program Televisi Seputar Indonesia di RCTI
}

\author{
Roswita Oktavianti, Budi Utami \\ Fakultas Ilmu Komunikasi, Universitas Tarumanagara \\ Jl. Letjen S Parman No 1, Jakarta Barat 11440 \\ roswitao@ fikom.untar.ac.id, budiu@fikom.untar.ac.id
}

Masuk tanggal : 23-02-2019, revisi tanggal : 30-03-2019, diterima untuk diterbitkan tanggal : 13-05-2019

\begin{abstract}
Brand of television programs has positive equity. It marks by the strength of audience awareness and familiarity with the name of the program. Marketer of television station are considered can create brand knowledge of the program in the audience memory. Nevertheless, as a business, television industries supposed to dynamically follow market need and wants. The brand of the television program which has strength awareness as well as the image on the audience memory will gradually change as much as a media business. This study using a qualitative method and case study as a research strategy to reveals the research problem about how the newsroom team arranged their strategies to maintain brand knowledge to the popularity program. The case study was conducted on RCTI news program "Seputar Indonesia" which has top of mind in audience memory then changed into "Seputar iNews". This study aiming to enquire how television broadcasting journalist strategies to maintain brand knowledge of their news program. The result is newsroom team have adapted and innovated their process to maintain brand knowledge. They were using main strategic such as maintain their replacement news program typically, maintain brand element whose have audiences top of mind, also using the digital platform.
\end{abstract}

Keywords: brand knowledge, program brand, news program, television industry

\begin{abstract}
Abstrak
Merek sebuah program televisi seringkali memiliki ekuitas yang positif. Hal ini ditandai dengan kesadaran dan keakraban yang kuat antara audiens dengan nama program televisi tersebut. Pemasar pada stasiun televisi telah mampu menciptakan pengetahuan terhadap merek (brand knowledge) dalam hal ini nama program acara, di dalam memori audiens. Namun, sebagai sebuah bisnis, industri televisi juga harus tetap bergerak dinamis mengikuti keinginan dan kebutuhan pasar. Merek program yang telah memiliki kesadaran dan citra (brand awareness dan brand image) yang kuat di dalam memori audiens, berubah mengikuti kepentingan bisnis media. Studi ini dilakukan dengan menggunakan pendekatan kualitatif dan metode studi kasus. Peneliti mengangkat permasalahan bagaimana tim redaksi pemberitaan, menyusun strategi guna mempertahankan brand knowledge sebuah program yang sudah populer di mata penonton. Studi kasus dilakukan terhadap program "Seputar Indonesia" di stasiun televisi RCTI yang sudah melekat di benak konsumen, namun kemudian berubah nama menjadi "Seputar iNews". Penelitian ini bertujuan untuk mengetahui strategi yang dilakukan oleh pelaku industri media penyiaran televisi dalam mempertahankan brand knowledge sebuah program berita. Hasilnya, tim redaksi pemberitaan sudah melakukan proses adaptasi dan inovasi untuk mempertahankan brand knowledge. Redaksi menggunakan strategi utama yakni mempertahankan ciri khas
\end{abstract}


program berita pengganti, mempertahankan elemen merek yang sudah menjadi top of mind penonton, serta memanfaatkan media digital dan platform lain dalam satu grup perusahaan.

Kata Kunci: pengetahuan merek, merek program, program berita, industri televisi

\section{Pendahuluan}

Redaksi pemberitaan RCTI pada 1 November 2017 mengganti nama program berita "Seputar Indonesia" menjadi "Seputar iNews". Penggantian nama program ini menjadi tantangan bagi redaksi dan pemasaran stasiun televisi RCTI. Pasalnya, nama program "Seputar Indonesia" sudah begitu melekat di benak audiens.

Program berita Seputar Indonesia RCTI lahir sebelum era kebebasan pers. Program berita ini tidak mengikuti gaya berita TVRI sebagai stasiun televisi milik pemerintah. TVRI berisi pemberitaan tentang keberhasilan pemerintah seperti gunting pita atau pidato pejabat. Sementara RCTI, menampilkan berbagai tayangan seperti misalnya kebakaran di daerah kumuh yang akan didirikan kondominium, pemogokan para buruh, demo mahasiswa dan Lembaga Swadaya Masyarakat di Gedung DPR/MPR, pembunuhan, banjir, serta berbagai kasus di pengadilan. RCTI pada saat itu lebih banyak menonjolkan gaya hiburan massa kelas menengah (Panjaitan \& Iqbal, 2006).

Paska integrasi dengan stasiun televisi berita iNews, Seputar Indonesia RCTI mengubah nama program dengan Seputar iNews. Ketika pemasar (marketer) menciptakan nama, logo, atau simbol baru untuk produk baru, dia telah menciptakan sebuah merek (brand). Pengetahuan tentang sebuah merek (brand image) yang diciptakan pemasar dari waktu ke waktu akan menentukan arah masa depan yang tepat dan tidak tepat bagi merek. Konsumen akan memutuskan berdasarkan pengetahuan merek mereka (Keller, 2012).

Pengetahuan merek merupakan kunci dalam menciptakan ekuitas merek. Ketika membangun pengetahuan merek, pemasar menciptakan efek berbeda untuk mendorong ekuitas merek. Pemasar menggunakan berbagai cara untuk mewakili bagaimana pengetahuan merek ada dalam memori konsumen. Pengetahuan merek memiliki dua komponen: yaitu brand awareness dan brand image. Kesadaran merek terkait dengan kekuatan simpul atau jejak merek di dalam memori/pikiran, yang dapat diukur sebagai kemampuan konsumen untuk mengidentifikasi merek dalam kondisi yang berbeda. Sementara, citra merek adalah persepsi konsumen tentang merek, seperti tercermin dari asosiasi merek yang terbentuk dalam memori konsumen (Keller, 2012).

Manajemen stasiun televisi membutuhkan strategi untuk tetap mempertahankan pengetahuan merek di tengah perubahan nama program serta hilangnya jam tayang utama program berita tersebut. Nama program berita merupakan salah satu elemen merek samahalnya dengan nama produk/jasa. Oleh karena itu, pemasar perlu mengelola nama program sepertihalnya elemen merek lainnya seperti logo, jingle, tagline, dsb. Hal ini dilakukan untuk tetap mempertahankan pengetahuan tentang merek tersebut di benak audiens. 
Roswita Oktavianti, Budi Utami : Strategi Mempertahankan Brand Knowledge Program Televisi Seputar Indonesia di RCTI

Penelitian terkait pengetahuan tentang sebuah merek program televisi masih belum banyak dilakukan di Indonesia. Penelitian terkait merek lebih banyak dikaitkan dengan perusahaan atau korporasi non-media. Misalnya, penelitian tentang Pengaruh Rebranding Terhadap Citra Bank Jambi Pada Nasabah mengukur sejauh mana pengaruh perubahan sejumlah elemen merek yang dilakukan Bank Jambi terhadap brand image (citra perusahaan) pada nasabah (Pratama, 2015).

Berdasarkan penelusuran, penelitian tentang merek program televisi dilakukan di Inggris dengan judul "Building Television Programme Brands in The Digital Multi-Channel World Perspectives of The UK Television Professionals". Penelitian ini menunjukkan bahwa merek siaran seringkali diibaratkan dengan merek retail. Dalam hal ini, saluran televisi menjadi toko, sementara program televisi menjadi produk atau line. Penelitian ini menggarisbawahi bahwa pertumbuhan merek komersial non-broadcast (atau pengiklan) akan memainkan peran utama dalam membentuk bagaimana program dan saluran merek dibangun. Pemasar televisi ( $T V$ marketers) berharap terlibat dengan program untuk mengevaluasi apa yang mereka lakukan pada merek saluran televisi secara keseluruhan, memposisikannya secara tepat dalam target pasar dan mengaplikasikan marketing tools yang mutakhir (Singh, 2003-2004).

Penelitian lain yang dilakukan di Inggris berjudul "The Impact of Program Brands on Consumer Evaluations of Television and Radio Broadcaster Brands", menguji bagaimana brand image penyiar berpengaruh pada keputusan pemprograman (programming). Hasilnya, persepsi dari keberhasilan (atau kegagalan) sebuah merek program mengalami efek pada peningkatan brand image penyiar. Biasanya terjadi pada program-program populer. Penelitian juga menunjukkan bahwa keharmonisan (atau keganjilan) brand image sebuah program menghasilkan peningkatan efek pada brand image penyiar. Penelitian ini menyarankan agar pengelola merek penyiar (broadcaster brand) harus peduli bahwa persepsi penyiar dapat meningkat ketika penonton atau pendengar menunjukkan bukti keberhasilan (atau kegagalan) program dan keharmonisan (atau keganjilan) sebuah program (Drinkwater \& Uncles, 2007).

Penelitian terkait merek pada program televisi juga dilakukan di AS. Penelitian berjudul "How to Advertise and Build Brand Knowledge Globally: Comparing Television Advertising Appeals Across Developed and Emerging Economies" menemukan bahwa daya tarik iklan memiliki hubungan dengan komponen brand knowledge melalui tanggapan internal konsumen, baik kognitif maupun afektif. Di negara dengan Produk Domestik Bruto (PDB) rendah, di mana konsumen ingin menjadi bagian dari budaya konsumen global, melihat merek sebagai sebuah cara untuk menunjukkannya. Oleh karena itu, praktisi iklan harus menggunakan daya tarik global saat ingin mengembangkan mereknya dan membangun brand knowledge. Kartun, anak-anak, dan analogi merupakan elemen yang diikutsertakan dalam pesan. Sebaliknya ketika, menargetkan konsumen di negara dengan PDB menengah, praktisi periklanan harus mencatat bahwa konsumen ini memiliki kepuasan aspirasi global dan ingin melihat sesuatu yang berbeda. Oleh karena itu, praktisi periklanan harus mengadopsi daya tarik berdasarkan pengalaman yang dapat membantu konsumen menciptakan kesadaran merek, memperbaiki sikap terhadap merek (brand attitude), dan mengembangkan 
keunikan merek (brand uniqueness). Pesan iklan harus berpusat pada fungsi produk yang tidak boleh digunakan (Zarantonello, Schmitt, \& Jedidi, 2014). Sementara penelitian ini ingin mengetahui bagaimana strategi mempertahankan brand knowledge sebuah program televisi?

RCTI merupakan stasiun televisi swasta tertua di Indonesia. Penelitian yang dilakukan terhadap 400 responden di Jakarta, menunjukkan RCTI merupakan stasiun televisi yang berada di puncak ingatan audiens atau top of mind. Penelitian tersebut menunjukkan bahwa tiga asosiasi yang membentuk brand image RCTI yakni RCTI Oke yang merupakan tagline/slogan RCTI, Indonesian Idol yang merupakan kontes menyanyi, dan Seputar Indonesia yang merupakan program berita di RCTI (Masruroh \& Indranto, 2008). Penelitian ini dilakukan pada masa ketika media online dan media sosial belum banyak diterapkan oleh organisasi media. Sementara artikel ini menyoroti strategi mempertahankan brand knowledge program televisi di tengah semakin tingginya ekspansi media dalam berbagai platform.

Sejauh ini penelitian terkait strategi mempertahankan brand knowledge lebih banyak berfokus pada produk dan jasa. Studi mengenai program acara televisi sebagai sebuah merek masih jarang dilakukan. Sementara artikel ini diharapkan bisa menjadi referensi bagi peneliti terkait strategi mempertahankan brand knowledge khususnya nama program di televisi yang sudah memiliki asosiasi kuat di benak konsumen.

\section{Metode Penelitian}

Penelitian ini menggunakan pendekatan kualitatif dan strategi penelitian berupa studi kasus (case study). Sebagai sebuah strategi penelitian, studi kasus digunakan dalam banyak situasi berkontribusi pada pengetahuan kami baik individu, kelompok, organisasi, sosial, politik, dan fenomena terkait lainnya (Yin, 2003). Studi kasus yang peneliti ambil yakni organisasi dalam hal ini redaksi pemberitaan RCTI. Peneliti menggunakan analisis single case karena dilakukan pada satu organisasi yakni tim redaksi pemberitaan RCTI.

Peneliti mengumpulkan data menggunakan sumber data primer dan sekunder. Sumber data primer diperoleh melalui wawancara. Wawancara dilakukan kepada narasumber Pemimpin Redaksi RCTI Atika Suri. Pertanyaan yang diajukan terkait dengan bagaimana redaksi sebagai pekerja media mempertahankan brand knowledge program berita "Seputar Indonesia".

Untuk mengetahui brand knowledge, peneliti menanyakan kepada narasumber terkait cara mempertahankan brand awareness dan brand image. Brand awareness seperti bagaimana membuat merek "Seputar Indonesia" tetap melekat dalam ingatan audiens meski sudah berganti nama menjadi "Seputar iNews", bagaimana melakukan branding dengan berbagai elemen merek seperti nama merek, logo, simbol, dan slogan. Sementara brand image yakni bagaimana audiens tetap mampu mengidentifikasi karakter program berita tersebut. Selain wawancara, peneliti juga menggunakan sumber data sekunder yakni data dokumen. 
Roswita Oktavianti, Budi Utami : Strategi Mempertahankan Brand Knowledge Program Televisi Seputar Indonesia di RCTI

Meskipun menggunakan analisis single case. Peneliti menggunakan validitas eksternal sebagai teknik keabsahan data, yang fokus pada pertanyaan tentang apakah temuan dari penelitian ini bisa digeneralisasi di luar konteks penelitian ini (Bryman, 2012). Artinya bahwa temuan penelitian ini bisa diaplikasikan pula (transferability) pada penelitian serupa pada program berita di televisi swasta lainnya. Peneliti juga melakukan penelitian serupa terkait strategi mempertahankan brand knowledge pada program berita Liputan 6 SCTV dengan metode serupa.

\section{Hasil Penemuan dan Diskusi}

\section{Program Berita RCTI}

PT Rajawali Citra Televisi (RCTI) merupakan pelaksana siaran sekaligus pelaku uji coba siaran televisi swasta berdasarkan SK Menpen No. 190A/Kep/Menpen/1987 tentang Siaran Saluran Terbatas TVRI pada 20 Oktober 1987. Kehadiran regulasi tersebut merupakan tonggak lahirnya televisi swasta komersial di Indonesia. RCTI ditetapkan sebagai stasiun televisi swasta pada 24 Agustus 1989.

Seputar Indonesia merupakan program berita tiga puluh menit yang dikelola bersama oleh RCTI dan Surya Citra Televisi (SCTV). Kedua stasiun televisi swasta itu bernaung di bawah PT Sindo Citra Media sebagai production house yang mengelola program informasi. RUU Penyiaran Tahun 1994 mewajibkan semua produksi berita dibuat sendiri oleh setiap stasiun televisi tanpa melibatkan pihak production house. Program berita Seputar Indonesia kemudian sepenuhnya diproduksi dan disiarkan oleh RCTI (LP3ES, 2006).

Saat ini RCTI merupakan salah satu stasiun televisi hiburan di bawah kelompok Media Nusantara Citra (MNC) milik pengusaha Harry Tanoesoedibjo. Grup media ini kemudian melahirkan stasiun televisi berita iNews TV. Program berita Seputar Indonesia kemudian berganti nama menjadi Seputar iNews pada 1 November 2017 (http://www.rcti.tv/program/seputar-inews-malam, 2017).

\section{Nama Program Berita "Seputar Indonesia" RCTI}

Program berita Seputar Indonesia di RCTI awalnya ditayangkan setiap pukul 18.30 WIB. Program berita ini digemari sehingga RCTI fokus mengembangkan divisi pemberitaan. Program berita lain muncul di jam tayang berbeda yakni Nuansa Pagi pada pagi hari, Buletin Siang pada siang hari, dan Buletin Malam pada tengah malam. Seiring berjalannya waktu, pihak RCTI menyadari bahwa agar sebuah brand menjadi top of mind maka nama program berita disamakan. Hal ini juga melihat pencapaian dua program berita di RCTI yang masuk nominasi Panasonic Awards yakni Buletin Siang dan Seputar Indonesia. Dengan memiliki dua nama program yang berbeda dalam satu tim redaksi, membuat suara penonton terpecah.

Ditambah lagi SCTV membuat program berita dengan satu nama yakni Liputan 6. Dengan sejumlah pertimbangan tersebut maka nama Seputar Indonesia diberlakukan untuk seluruh program berita RCTI. Menurut narasumber, ini 
merupakan dinamika newsroom dan bisnis media. Pada 1 November 2017 seluruh program berita dalam kelompok MNC berubah menjadi iNews

\section{Nama Program Berita "Seputar iNews" RCTI}

Dalam rangka efisiensi sekaligus memperkenalkan televisi berita iNews agar diingat penonton dan mampu bersaing dengan televisi berita lain, maka seluruh program berita dalam grup MNC menggunakan nama iNews. Seputar Indonesia berubah nama menjadi Seputar iNews.

Menurut narasumber, perubahan nama ini dilakukan untuk efisiensi. Seluruh program berita dalam grup $\mathrm{MNC}$, berada di bawah payung tim pemberitaan iNews. Harapannya agar iNews bisa cepat menjadi top of mind penonton. Narasumber mencontohkan, selain Seputar Indonesia di RCTI berubah nama menjadi Seputar iNews, juga terdapat program berita di stasiun MNC TV dengan nama program Lintas iNews, dan program berita di stasiun Global TV dengan nama program Buletin iNews.

Kata iNews berarti Indonesia, bisa juga "I" dalam bahasa Inggris berarti "saya". Perubahan nama program berita di grup MNC menjadi iNews dilakukan serentak yakni pada 1 November 2017. Program berita Seputar iNews terdiri dari Seputar iNews Pagi dengan durasi 60 menit, Seputar iNews Siang dengan durasi 45 menit, dan Seputar iNews Malam 30 menit. Seputar iNews Siang awalnya memiliki durasi 30 menit. Namun setelah program berita sore tidak lagi tayang maka durasi 15 menit dialihkan ke Seputar iNews Siang sehingga durasi berita dari semula 30 menit menjadi 45 menit. Di RCTI, Seputar iNews masih menjadi andalan dalam mendapatkan iklan.

Seputar iNews Pagi mengangkat berita-berita yang diperkirakan mempengaruhi aktivitas penonton seperti terjadi kebakaran dan demonstrasi di Jakarta sehingga penonton bisa mengantisipasi perjalanan melewati area tersebut. Seputar iNews Siang memiliki target penonton ibu-ibu sehingga isu ekonomi, politik dan hukum dikemas lebih ringan agar penonton mampu mengikuti isu tersebut. Setelah program berita Seputar iNews Sore ditiadakan, maka program Seputar iNews Siang menjadi berita utama.

Sama seperti Seputar Jakarta dan Seputar Indonesia, Seputar iNews juga menyajikan berita dengan bahasa yang lebih ringan atau membumi. Berita ekonomi misalnya diangkat dengan lebih ringan dan berdampak langsung pada masyarakat, seperti berita inflasi dikaitkan dengan kenaikan harga cabai, Bahan Bakar Minyak atau gas murah, dan sebagainya.

Selain Seputar iNews, juga terdapat Sekilas iNews yang menggantikan nama program Sekilas Info. Sekilas iNews awalnya hanya berdurasi 1 menit dan ditayangkan pada pukul 9, pukul 10, pukul 14, pukul 15, dan pukul 16. Namun, dengan dihilangkannya Seputar iNews Sore maka durasi Sekilas iNews ditambah dari semula 1 menit menjadi 3 menit.

\section{Konten Berita "Seputar iNews" RCTI}

Menurut narasumber, program Seputar Indonesia hanya mengalami perubahan nama program menjadi Seputar iNews. Sementara tim redaksi, cara menggarap berita, ciri khas pemberitaan masih sama. Hal ini juga yang disampaikan 
oleh pemilik dari Grup MNC, Hary Tanoesoedibjo. Menurut narasumber, pemilik Grup MNC menyatakan bahwa perubahan nama program tidak perlu berdampak pada "dapur" newsroom. Tim redaksi menjalankan program berita sebagaimana biasanya.

Perubahan ini sebetulnya tidak menganggu eksistensi penonton. Pasalnya, program berita "Seputar Indonesia" yang kini berganti nama menjadi "Seputar iNews" diuntungkan dengan nama besar RCTI. Sebagai stasiun televisi swasta pertama di Indonesia, nama program berita Seputar Indonesia atau RCTI sudah lama berada di benak pemirsa.

Menurut narasumber, dengan persamaan nama program berita iNews di semua stasiun televisi dalam Kelompok MNC bukan berarti masing-masing redaksi tidak memiliki karakteristik pemberitaan. Karakter pemirsa TV berita dan TV hiburan sangat berbeda. Televisi berita sudah memiliki segmen yang jelas. Penonton yang ingin mendapatkan informasi/pemberitaan isu harian seperti politik, hukum, dan sosial, akan memilih menonton berita. Dari sisi status sosial ekonomi juga berbeda.

Sementara itu, televisi hiburan cenderung memiliki penonton yang tidak terlalu membutuhkan informasi penting. Oleh karena itu, berita yang ditayangkan RCTI sebagai televisi hiburan berbeda dengan berita yang ditayangkan di televisi berita dalam satu kelompok seperti iNews TV. Dengan target penonton ibu-ibu yang gemar menonton sinetron maka program berita di RCTI lebih menggunakan bahasa yang sederhana agar penonton menganggap informasi itu penting bagi mereka.

Menurut narasumber, program berita di televisi hiburan justru lebih lengkap daripada televisi berita. Hal ini karena televisi berita menayangkan informasi lebih dulu meski masih pada tataran permukaan. Dengan tuntutan tersebut, maka televisi hiburan harus bisa membuat berita dengan lebih lengkap atau lebih dalam agar berbeda dengan televisi berita.

\section{Platform Digital Seputar iNews}

Seputar iNews memiliki tim media sosial yang mengelola Instagram, Twitter, Facebook, Youtube, dan MeTube. MeTube.id merupakan platform digital yang dimiliki oleh MNC Group. Di layanan berbagi video ini, berita yang tayang di Seputar iNews dibagi/dipotong-potong agar durasi lebih singkat. Saat ini anakanak muda lebih banyak menggunakan gadget termasuk untuk menonton namun dalam bentuk cuplikan.

Menurut narasumber, platform media sosial ini cukup bisa menjangkau penonton generasi milenial, walau masih belum bisa mengungguli stasiun televisi lain seperti Net.TV. Meski menggunakan platform digital, namun program berita Seputar iNews RCTI tetap mengunggulkan program berita di televisi. Hal ini karena lembaga rating Nielsen Media Research menjadi acuan para pemasang iklan. Sementara, pendistribusian berita Seputar iNews RSTI di media sosial belum mampu meraup iklan sebanyak televisi. 


\section{Mempertahankan Brand Awareness dan Brand Image}

Pengetahuan merek terdiri atas kesadaran merek (brand awareness) dan citra merek (brand image). Kesadaran merek merupakan kemampuan konsumen untuk mengidentifikasi merek dalam kondisi yang berbeda. Menurut Keller (2012), kesadaran merek terdiri atas brand recognition (pengenalan merek) dan brand recall (pengingatan/pemanggilan kembali terhadap merek lewat kategori tertentu). Dalam penelitian ini kesadaran merek ditunjukkan dari bagaimana tim redaksi Seputar iNews RCTI membuat merek program berita tersebut tetap dikenali dan diingat oleh penonton, lewat elemen merek. Elemen merek diantaranya nama merek, logo, slogan, juru bicara, kemasan, dll.

Sementara itu, citra merek merupakan persepsi konsumen tentang merek, seperti tercermin dari asosiasi merek yang terbentuk dalam memori konsumen. Asosiasi merek dibentuk dengan beberapa cara yakni dari pengalaman langsung, online surfing, informasi dari sumber komersial, dari mulut ke mulut, serta asumsi/kesimpulan yang dibuat konsumen tentang merek itu sendiri. Asosiasi tersebut mencerminkan karakteristik produk atau aspek dari produk (Keller, 2012).

Citra merek terdiri atas brand attribute (fitur deskriptif yang menjadi ciri produk atau jasa), dan brand benefit (nilai dan makna pribadi yang dilekatkan konsumen pada atribut produk atau jasa). Citra merek bervariasi, tergantung pada segmen konsumen atau pasar. Dalam penelitian ini, citra merek yang dimaksud yakni bagaimana cara redaksi tim program berita Seputar iNews RCTI

membuat audiens tetap mampu mengidentifikasi karakter program berita tersebut, serta bagaimana membangun kepercayaan terhadap merek (seperti kekuatan, kesukaan, dan keunikan), dll.

Beberapa temuan terkait strategi yang digunakan oleh tim redaksi pemberitaan untuk tetap membangun kesadaran merek dan citra merek (program berita), yakni: mempertahankan kualitas berita dan ciri khas pada program berita pengganti, mempertahankan elemen merek, dan memanfaatkan media sosial,

Pertama, mempertahankan kualitas berita dan ciri khas pada program berita pengganti. Perubahan nama program Seputar iNews RCTI tidak mempengaruhi kualitas pemberitaan. Seputar iNews RCTI memiliki karakteristik pemberitaan yang berbeda dengan berita dalam satu grup perusahaan. Ini yang disebutkan bahwa persaingan bukan hanya terjadi dengan program atau produk perusahaan dari media lain tetapi dengan program atau produk dalam satu grup media itu sendiri (Oktavianti, 2018).

Sebagai televisi hiburan dan komersial, berita yang ditayangkan harus sesuai dengan target penonton.Televisi hiburan menggunakan strategi pemasaran yang dikenal sebagai "segmentasi'. Melalui segmentasi, perusahaan media mengubah orientasi dengan mengacu pada penonton. Dari awalnya mencoba untuk menjangkau sebanyak mungkin penonton menjadi hanya berusaha menjangkau penonton yang menarik minat pengiklan (Herrick, 2012).

RCTI merupakan televisi hiburan yang memiliki penonton berita dengan segmen ibu-ibu rumah tangga, sehingga bahasa yang digunakan dalam pemberitaan dikemas lebih sederhana dan disesuaikan dengan kegiatan audiens. Berita yang ditayangkan baik isu politik, hukum, ekonomi, dan sosial, merupakan isu ringan yang kerap ditemui sehari-hari. 
Roswita Oktavianti, Budi Utami : Strategi Mempertahankan Brand Knowledge Program Televisi Seputar Indonesia di RCTI

Kedua, mempertahankan elemen merek. Elemen merek merupakan komponen yang berbeda - bisa berupa nama, logo, simbol, desain kemasan, atau karakteristik lain - yang mengidentifikasi suatu produk dan membedakannya dari yang lain (Keller, 2012). Dalam program berita televisi, elemen merek yang dibahas yakni berupa nama program, logo, slogan/tagline.

Program berita di RCTI awalnya menggunakan nama program yang berbeda-beda seperti Seputar Indonesia dan Buletin Siang. Namun, redaksi pemberitaan RCTI kemudian menyadari bahwa agar sebuah brand menjadi top of mind maka nama program berita disamakan menjadi Seputar Indonesia. Keputusan mengubah program berita RCTI menjadi Seputar iNews semata-mata untuk mengangkat brand stasiun televisi baru iNews yang masih satu keluarga. Kendati demikian, kata "Seputar" tetap digunakan pada program berita yang baru.

Logo perubahan tampak pada nama program dari semula "Seputar Indonesia" menjadi "Seputar iNews". Namun, tidak terdapat perubahan pada warna yang didominasi biru, abu-abu, dan merah. Elemen lain seperti burung rajawali juga tetap menjadi ciri khas logo program.
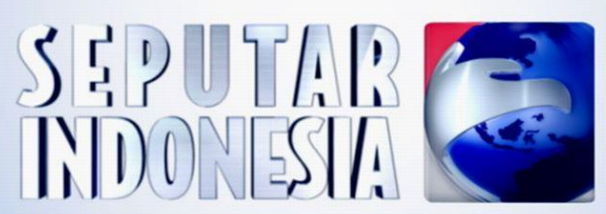

Gambar 1: Logo Seputar Indonesia RCTI (Sumber: http://news.okezone.com)

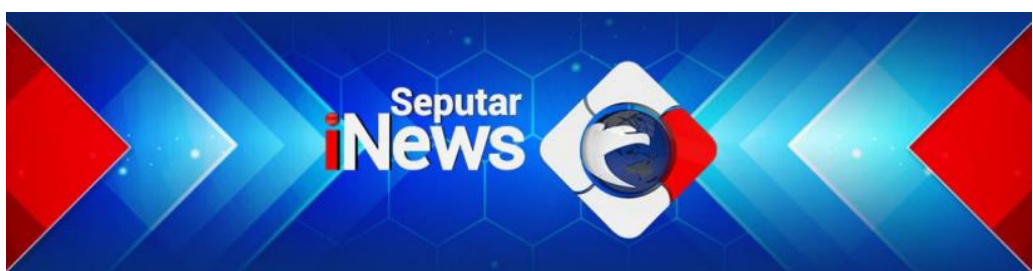

Gambar 2: Logo Seputar iNews RCTI (Sumber: metube.id)

Ketiga, memanfaatkan media sosial. Pengaruh media sosial terhadap ekuitas merek yang cukup besar ini dibuktikan oleh penelitian yang dilakukan oleh Kinanti dan Putri terhadap merek jasa kecantikan di media sosial Instagram. Hasilnya, media sosial berpengaruh signifikan terhadap ekuitas merek dengan indikator tertinggi yakni konteks, koneksi, dan komunikasi (Kinanti \& Putri, 2017). Penelitian yang dilakukan Ummi Salamah terhadap bakal calon presiden RI pada Pilpres 2014 menunjukkan bahwa selain visibilitas di media, kontak langsung yang dialami pemilih dengan brand juga menentukan tingkat pengenalan merek. Artinya barang yang seringkali melakukan kontak langsung dengan audiensnya adalah brand yang relatif lebih dikenal dibandingkan dengan brand yang jarang menjalin kontak langsung (Salamah, 2015). Oleh karena itu, tim redaksi membuat divisi 
media sosial yang khusus menangani media sosial program berita agar dekat dengan penonton muda.

Pemimpin redaksi RCTI, Atika Suri mengatakan bahwa televisi menjadi sesuatu yang konvensional. Generasi muda sudah tidak lagi menonton televisi. Televisi saat ini ditonton untuk mengonfirmasi berita yang pemirsa baca di media online. Televisi bukan lagi sumber informasi pertama. Saat ini anak-anak muda lebih banyak menggunakan perangkat elektronik/gadget untuk menonton. Berita yang ditonton pun berdurasi singkat atau dalam bentuk cuplikan. Oleh karena itu, Seputar iNews memiliki tim media sosial yang mengelola Instagram, Twitter, Facebook, Youtube, dan MeTube. MeTube merupakan platform digital yang dimiliki oleh MNC Group. Di layanan berbagi video ini, berita yang tayang di Seputar iNews dibagi/dipotong-potong agar durasi lebih singkat. Platform media sosial ini dinilai bisa menjangkau penonton generasi milenial.

\section{Simpulan}

Program berita memiliki peran penting bagi perusahaan televisi. Ketika sebuah program berita di televisi hiburan yang sudah memiliki brand awareness dan brand image berganti nama. Tim redaksi melakukan strategi untuk tetap mempertahankan brand knowledge penonton terhadap program berita tersebut. Strategi yang dilakukan yakni: mempertahankan ciri khas program berita pengganti, mempertahankan elemen merek yang sudah menjadi top of mind penonton seperti nama program berita, logo, jingle, dan tagline; memanfaatkan media digital seperti website, media sosial, layanan berbagi video, dan platform lain dalam satu grup perusahaan.

\section{Ucapan Terima Kasih}

Peneliti menyampaikan terimakasih sebesar-besarnya kepada Direktorat Penelitian dan Pengabdian Kepada Masyarakat Universitas Tarumanagara atas terselenggaranya penelitian ini. Terimakasih juga kepada Pemimpin Redaksi RCTI selaku narasumber.

\section{Daftar Pustaka}

Bryman, A. (2012). Social Research Methods 4th Edition. New York: Oxford University Press.

Drinkwater, P., \& Uncles, M. (2007). The Impact of Program Brands on Consumer Evaluations of Televison and Radio Broadcaster Brands. Journal of Product \& Brand Management, 3(3), 178-187. doi:10.1108/10610420710751555

Herrick, D. F. (2012). Media Management in the Age of Giant: Business Dynamics of Journalism. Alburqueque: University of New Mexico Press.

http://www.rcti.tv/program/seputar-inews-malam. (2017). Retrieved Februari 16, 2018, from http://www.rcti.tv.

Keller, K. L. (2012). Strategic Brand Management Building, Measuring, and Managing Brand Equity 4th Edition. Essex: Pearson. 
Roswita Oktavianti, Budi Utami : Strategi Mempertahankan Brand Knowledge Program Televisi Seputar Indonesia di RCTI

Kinanti, S. P., \& Putri, B. P. (2017, Juli). Pengaruh Media Sosial Instagram @ Zapcoid Terhadap Brand Equity Zap Clinic. Jurnal Komunikasi, 9(1), 5364. doi:10.24912/jk.v9i1.164

LP3ES, T. R. (2006). Jurnalisme Liputan 6 SCTV Antara Peristiwa dan Ruang Publik. Jakarta: Pustaka LP3ES.

Masruroh, \& Indranto, A. (2008, Maret). Analisis Elemen Ekuitas Merek RCTI Dalam Persaingan Industri Televisi Swasta di Indonesia: Studi Kasus Pada Empat Perguruan Tinggi Swasta Terkemuka di Jakarta. The Winners, 9(1), 62-73. doi:10.21512/tw.v9i1.731

Oktavianti, R. (2018). Competitive Advantage of Investigation Products in Media Industrialization. IFIM's Focus International Journal of Management, 14(1), 6-12.

Panjaitan, E. L., \& Iqbal, T. D. (2006). Matinya Rating Televisi, Ilusi Sebuah Netralitas. Jakarta: Yayasan Obor Indonesia.

Pratama, M. I. (2015). Pengaruh Rebranding Terhadap Citra Bank Jambi Pada Nasabah. Jurnal Kajian Komunikasi, 3(2), 140-147. doi: https://doi.org/10.24198/jkk.v3i2.7404

Salamah, U. (2015). Brand Pemimpin Politik. Jakarta: Makna Informasi.

Singh, S. (2003-2004). Building Television Programme Brands in The Digital Multi-Channel World-Perspectives of The UK Television Professionals. United Kingdom: Bournemouth University. Retrieved Februariy 17, 2018, from

http://eprints.bournemouth.ac.uk/12157/1/Building_Television_Programm e_Brands.pdf.

Yin, R. K. (2003). Case Study Research Design \& Methods Third Edition. Thousand Oaks, California: Sage Publications.

Zarantonello, L., Schmitt, B. H., \& Jedidi, K. (2014). How to Advertise and Build Brand Knowledge Globally: Comparing Television Advertising Appeals Across Developed and Emerging Economies. Journal of Advertising Research, 54(4), 1-23. doi:10.2501/JAR-54-4-420-434 